Article

\title{
Effect of 3-Phenyllactic Acid and 3-Phenyllactic Acid-Producing Lactic Acid Bacteria on the Characteristics of Alfalfa Silage
}

\author{
Zhe $\mathrm{Wu} * \mathbb{D}$, Shengyang $\mathrm{Xu}$, Ying Yun, Tingting Jia and $\mathrm{Zhu} \mathrm{Yu}$ * \\ College of Grassland Science and Technology, China Agricultural University, Beijing 100093, China; \\ sy20193040640@cau.edu.cn (S.X.); yunying1224@yeah.net (Y.Y.); B20163040303@cau.edu.cn (T.J.) \\ * Correspondence: wuzhe@cau.edu.cn (Z.W.); yuzhu33150@sina.com (Z.Y.); Tel.: +86-10-62734593 (Z.W.); \\ $+86-10-62733414$ (Z.Y.)
}

Received: 13 November 2019; Accepted: 24 December 2019; Published: 31 December 2019

\begin{abstract}
In this study, an experiment was performed to evaluate the effect of lactic acid bacteria and 3-phenyllactic acid (PLA) on the fermentation quality and chemical composition of alfalfa silage. Several PLA-tolerant strains were screened from silages and identified. The selected strains $\left(1 \times 10^{6}\right.$ colony forming units $/ \mathrm{g}$ fresh alfalfa) and PLA $(1.0,2.0$, or $3.0 \mathrm{~g} / \mathrm{kg}$ ) were applied to alfalfa before ensiling. After 45 days of storage, the silages were unsealed and subjected to component analysis. Biochemical methods and 16S rDNA gene sequencing were used for the identification of the two strains as Lactobacillus plantarum. The characteristics of chemical and fermentation compounds indicated that PLA and the two strains efficiently improved the quality of the alfalfa silage. It can be concluded that the use of the strains and PLA can significantly improve the quality of silage.
\end{abstract}

Keywords: 3-phenyllactic acid; alfalfa silage; Lactobacillus plantarum; strain screening

\section{Introduction}

Alfalfa silage is a rough feed commonly used for ruminants because it is nutritious. During the process of wilting and storage, some of the proteins in alfalfa silage break down to nonprotein nitrogen (NPN), resulting in poor nitrogen utilization by ruminants [1]. Furthermore, the dietary N that cannot be utilized by ruminants is excreted into the environment [2]. Thus, to meet the $\mathrm{N}$ demand of ruminants fed silage-based diets, reduced protein degradation during silage is important.

To obtain high-quality alfalfa silage, a variety of additives are added during the process of making silage, such as lactic acid bacteria, propionic acid, formic acid, cellulase, tannin, and benzoic acid [2-5]. The addition of these additives not only improves the feeding value but also improves the stability of the alfalfa silage.

Researchers isolated lactic acid bacteria from fresh rumen fluid and silages to stimulate the ensiling process [4]. Lactic acid bacteria with high growth rates, fibrolytic activities, and ferulic acid activities were suggested to be efficient in improving the quality of alfalfa silage [4]. Currently, changes in the content of functional composition during alfalfa ensiling have attracted much attention [6,7].

The chemical 3-Phenyllactic acid (PLA) was first identified as an antifungal compound in lactic acid bacteria in 2002 [8]. PLA is a by-product of phenylalanine (Phe) metabolism and has efficient antibacterial action against food-spoilage microorganisms $[9,10]$. 
The biosynthesis pathway of PLA is shown in Figure 1. Phe can be generated from either the Phe biosynthesis pathway or protein degradation. Phenylpyruvate is one of the intermediate products of Phe biosynthesis, and it is produced by transamination of Phe [11,12]. Phenylpyruvate can be decarboxylated, reduced, and chemically oxidized, resulting in phenylacetaldehyde, PLA, and benzaldehyde, respectively. PLA is considered a natural environmentally friendly organic acid, and its antimicrobial activity is safe and efficient [10]. Furthermore, it has promising applications as an additive for feed and as an antiseptic agent for food.

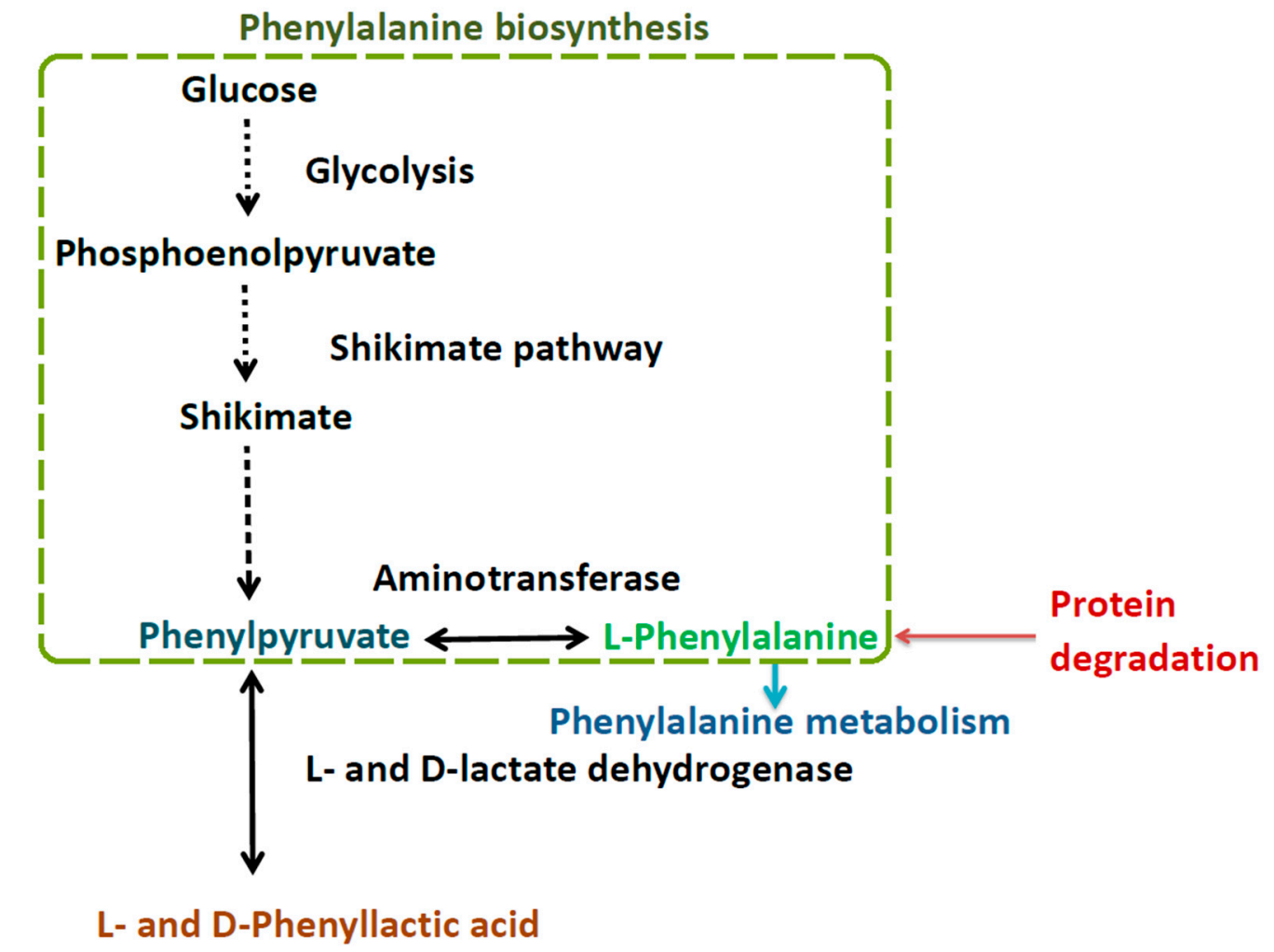

Figure 1. Biosynthesis of 3-Phenyllactic acid.

PLA showed positive biofunction when fed to animals. L-PLA could replace $70.1 \%$ Phe in the diets of chicks and mice [13]. It was reported that PLA might have positive effects to the immune system of hens and pigs $[14,15]$. PLA improved the egg production rate, and eggshell breaking strength in laying hens over a short term. It increased immune-related blood cell counts in weanling and growing pigs [15]. Furthermore, the odor of PLA was less pronounced than those of other organic acids. The above results indicate that PLA may be used as an alternative to antibiotics for growth promotion. However, no studies have reported the effect of PLA on plants as a silage additive.

To study the effects of lactic acid bacteria and PLA on the quality of alfalfa silage, the fermentation and nutrition characteristics of silage were analyzed.

\section{Materials and Methods}

\subsection{Lactic Acid Bacteria Screening}

Lactic acid bacteria were collected from pickles, alfalfa silage, corn silage, and oat silage. Twenty grams of fresh samples was mixed with $20 \mathrm{~g}$ of distilled water for $10 \mathrm{~min}$ in a blender. The mixture was centrifuged, the supernatant was spread on solid Man, Rogosa, Sharpe (MRS) medium supplemented with $10 \mathrm{~g} / \mathrm{L}$ of PLA, and the plates were incubated at $30^{\circ} \mathrm{C}$. A total of 48 colonies was picked and transferred to liquid MRS medium in triplicate. After incubation at $30^{\circ} \mathrm{C}$ for $24 \mathrm{~h}$, the OD and the 
organic acid were quantified by spectrophotography and HPLC. Two strains (M1 and M3) with similar growth rates and different PLA production efficiencies were chosen.

\subsection{LAB Identification}

The genomic DNA of M1 and M3 was extracted with the DNA Isolation Kit (Tiangen Biotech Co., Ltd., Beijing, China). Genomic DNA was used as a template for 16S rDNA amplification. The following primers were used: 25f (5'-AACTGAAGAGTTTGATCCTGGCTC-3') and 1492r (5'-TACGGCTACCTTGTTACGACT-3') [16]. The PCR products were gel-purified and Sanger sequenced by Majorbio Company (Beijing, China). The sequences were aligned in NCBI.

Carbohydrate fermentation was determined in carbohydrate-free MRS medium with filter-sterilized carbohydrates [17]. After inoculating MRS with $1 \%$ overnight LAB culture, the medium for carbohydrate fermentation analysis was incubated at $37^{\circ} \mathrm{C}$ for $48 \mathrm{~h} . \mathrm{OD}_{620}$ readings above 0.5 were identified as positive.

\subsection{Determination of $P L A$}

Fermented medium was centrifuged at $10,000 \times g$ for $20 \mathrm{~min}$, and the supernatant was used for the organic acid analysis. PLA and other organic acids were determined on an Agilent 1100 HPLC system, using the method described by Guo et al. [18].

\subsection{Additive Preparation}

The strains M1 and M3 were cultured in $3 \mathrm{~mL}$ of liquid MRS medium for $20 \mathrm{~h}$, and then $1 \mathrm{~mL}$ of broth was transferred to $100 \mathrm{~mL}$ of liquid MRS, respectively. The $100 \mathrm{~mL}$ of liquid MRS was incubated at $30^{\circ} \mathrm{C}$. After incubating for $24 \mathrm{~h}, 10 \mathrm{~mL}$ of broth from $100 \mathrm{~mL}$ of liquid MRS was transferred to $1 \mathrm{~L}$ of MRS medium and cultured at $30^{\circ} \mathrm{C}$ for $24 \mathrm{~h}$. The cells were collected by centrifugation at $6800 \times g$ for 30 min and washed with PBS buffer ( $\mathrm{pH}$ 8.0). The LAB cells were mixed with non-fat milk solution and then lyophilized. The population of the viable cells per gram was assessed by plate cultivation.

\subsection{Silage Making}

Alfalfa was harvested during the early blooming period (the first cutting). It was withered to a water content of $67 \%$ and chopped into fragments of approximately $0.5 \mathrm{~cm}$; the two factor treatments $(3 \times 4)$ were designed as factor A, CK (water), M1 $\left(1 \times 10^{6} \mathrm{cfu} / \mathrm{g}\right.$ fresh alfalfa), and M3 $\left(1 \times 10^{6} \mathrm{cfu} / \mathrm{g}\right.$ fresh alfalfa); and factor B, 0, 1, 2, or $3 \mathrm{~g}$ PLA $/ \mathrm{kg}$ fresh alfalfa. The fresh material and additives were mixed thoroughly. A total of $70 \mathrm{~g}$ of the mixtures of each treatment was packed into $100 \mathrm{~mL}$ plastic jars. Three replicates were made for each treatment. The triplicate silos for each treatment were well sealed and stored at room temperature for 45 days.

\subsection{Analytical Methods}

For each sample, the materials in the bag were well mixed and divided into 4 parts when the silo was opened. A total of $17.5 \mathrm{~g}$ of silage sample was blended with $157.5 \mathrm{~g}$ deionized water in a working-blender jar. The extract was centrifuged at $10,000 \times g$ and then filtered using $0.22 \mu \mathrm{m}$ microfiltration membranes. The supernatant was used to value the $\mathrm{pH}$, ammonia nitrogen, and organic acid. Another quarter of silage sample were dried at $65^{\circ} \mathrm{C}$ for $48 \mathrm{~h}$, in an oven. Then, the dry sample was ground, screened, and used for chemical composition (dry matter (DM), neutral detergent fibre (NDF), acid detergent fibre (ADF), crude protein (CP) and water-soluble carbohydrate (WSC)) analysis by the methods of Guo et al. [18]. 


\subsection{Statistical Analysis}

The effects of LAB strains and PLA on the principal characteristics of alfalfa silages were analyzed by two-way analysis of variance. The fixed effects of additives were analyzed by using the same method. The SPSS19.0 software (IBM Corp., Armonk, NY, USA) was employed to evaluate data. The differences between the treatment means and the significance were determined at the 0.05 level of probability and were evaluated by Duncan's multiple range tests. The R soft package was utilized for correlation analysis between fermentation and chemical characteristics of alfalfa silages.

\section{Results}

\subsection{Strain Screening and Characteristics of the Strains}

Most PLA-producing strains were isolated from pickles [9]. As a newly found antifungal compound, PLA showed inhibitory effects toward yeast and mold species, such as Penicillium, Aspergillus, Candida, Rhodotorula, and Rhizopus species [10-12,19]. PLA was also detected in silages, and its presence might relate to LAB [20]. Xu et al. reported that the content of PLA in silage was probably produced by L. acetotolerans and positively correlated with L. plantarum [20]. It was speculated that the antifungal activity of LAB strains was positively related to the metabolic content of PLA [12].

In the current study, the LAB strains were collected from silages and pickles. The PLA-tolerant bacteria were obtained on solid MRS supplemented with PLA. Then, the PLA-tolerant LAB strains were screened in order to obtain strains with the ability to produce PLA. In this study, eight strains $(\mathrm{X} 1-\mathrm{X} 6, \mathrm{X} 8$, and $\mathrm{X} 9)$ from alfalfa silage, six strains (Y1-Y6) from pickled watermelon, nine strains (P1-P9) from corn silage, nine strains (S1-S9) from oat silage, two strains (C1 and C2) from pickled carob, five strains (M1-M5) from pickled cucumber, three strains (A2, A4, and A5) from pickled radish, and six strains (N1-N6) from pickled Chinese cabbage were selected. Among the 48 strains obtained, 42 could grow rapidly in liquid MRS, and 39 could reduce the $\mathrm{pH}$ of the medium to less than 4.5.

Most of the candidate strains showed vigorous growth in liquid MRS medium and produced different organic acid contents (Figure 2). Based on the $\mathrm{OD}_{620}$ and the $\mathrm{pH}$ in liquid MRS medium, eleven strains with similar growth rates and abilities to produce organic acid were selected for further analysis. The organic acid in the supernatant was analyzed by HPLC. As shown in Table 1, the selected strains showed differences in their ability to produce PLA. Nine strains produced over $0.050 \mathrm{mg} / \mathrm{mL}$ of PLA. Most of the strains selected from homemade pickles produced a higher content of PLA than the LAB from silages, which revealed that silage and homemade pickles were potential resources for screening for PLA-producing strains. Two of the eleven strains were chosen based on their outstanding lactic acid- and PLA-producing abilities. The identities of the two strains designated M1 and M3 were determined by analyzing the $16 \mathrm{~S}$ rDNA, which was similar to the $15 \mathrm{~S}$ rDNA of L. plantarum. The $16 \mathrm{~S}$ rDNA of M1 and M3 showed 100\% and 99\% identity to L. plantarum strain KCCP 11,446 (Accession No. MN453623.1) and L. plantarum strain gp1 (Accession No. KM495856.1), respectively. The screened strains, M1 and M3, both exhibited a high growth rate, and lactic acid productivity thus showed potential use for silage making. Then, the carbohydrate fermentation was performed. The two strains had similar carbohydrate-fermentation abilities (Table 2), similar abilities to produce lactic acid, and different abilities to convert PLA from glucose (Table 1). 

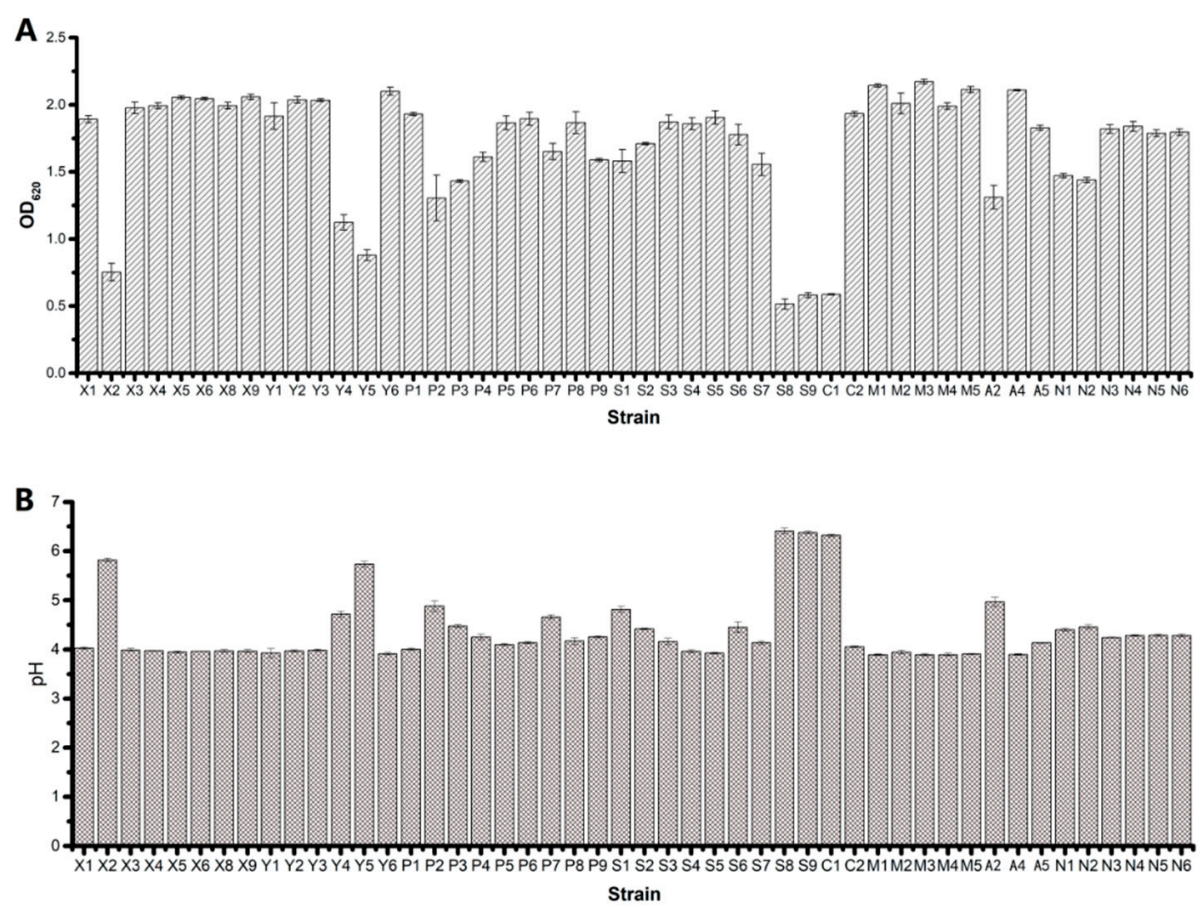

Figure 2. The growth (A) and $\mathrm{pH}(\mathbf{B})$ of the strains incubated in MRS medium.

Table 1. The acid production of lactobacillus bacteria cultivated in MRS medium.

\begin{tabular}{cccccc}
\hline Strain & $\begin{array}{c}\text { Lactic Acid } \\
\left(\mathbf{m g} / \mathbf{m L}^{\mathbf{2}}\right)\end{array}$ & $\begin{array}{c}\text { Acetic Acid } \\
(\mathbf{m g} / \mathbf{m L})\end{array}$ & $\begin{array}{c}\text { Propionic Acid } \\
\mathbf{( m g / m L})\end{array}$ & $\begin{array}{c}\text { Butyric Acid } \\
(\mathbf{m g} / \mathbf{m L})\end{array}$ & $\begin{array}{c}\text { Phenyllactic Acid } \\
(\mathbf{m g} / \mathbf{m L})\end{array}$ \\
\hline X5 & $10.82 \pm 0.08 \mathrm{de}$ & $2.87 \pm 0.02 \mathrm{bc}$ & $2.19 \pm 0.00 \mathrm{a}$ & $\mathrm{ND}$ & $0.054 \pm 0.001 \mathrm{~cd}$ \\
X6 & $10.65 \pm 0.06 \mathrm{ef}$ & $2.87 \pm 0.00 \mathrm{bc}$ & $2.17 \pm 0.01 \mathrm{ab}$ & $\mathrm{ND}$ & $0.053 \pm 0.001 \mathrm{~cd}$ \\
X9 & $10.50 \pm 0.24 \mathrm{f}$ & $2.86 \pm 0.02 \mathrm{~cd}$ & $2.15 \pm 0.04 \mathrm{bc}$ & $\mathrm{ND}$ & $0.051 \pm 0.000 \mathrm{~d}$ \\
Y2 & $10.50 \pm 0.18 \mathrm{f}$ & $2.87 \pm 0.01 \mathrm{bc}$ & $2.18 \pm 0.02 \mathrm{ab}$ & $\mathrm{ND}$ & $0.058 \pm 0.001 \mathrm{~b}$ \\
Y3 & $10.45 \pm 0.14 \mathrm{f}$ & $2.89 \pm 0.01 \mathrm{ab}$ & $2.12 \pm 0.01 \mathrm{~cd}$ & $\mathrm{ND}$ & $0.052 \pm 0.001 \mathrm{~cd}$ \\
Y6 & $10.97 \pm 0.22 \mathrm{bcde}$ & $2.89 \pm 0.01 \mathrm{ab}$ & $2.17 \pm 0.01 \mathrm{ab}$ & $\mathrm{ND}$ & $0.052 \pm 0.001 \mathrm{~cd}$ \\
M1 & $11.28 \pm 0.08 \mathrm{ab}$ & $2.80 \pm 0.01 \mathrm{f}$ & $1.97 \pm 0.02 \mathrm{f}$ & $\mathrm{ND}$ & $0.066 \pm 0.000 \mathrm{a}$ \\
M2 & $10.90 \pm 0.37 \mathrm{cde}$ & $2.86 \pm 0.02 \mathrm{~cd}$ & $2.02 \pm 0.03 \mathrm{e}$ & $\mathrm{ND}$ & $0.052 \pm 0.001 \mathrm{~cd}$ \\
M3 & $11.33 \pm 0.12 \mathrm{a}$ & $2.84 \pm 0.01 \mathrm{e}$ & $2.13 \pm 0.01 \mathrm{~cd}$ & $\mathrm{ND}$ & $0.055 \pm 0.000 \mathrm{c}$ \\
M5 & $11.02 \pm 0.06 \mathrm{abcd}$ & $2.84 \pm 0.01 \mathrm{de}$ & $2.13 \pm 0.01 \mathrm{~cd}$ & $\mathrm{ND}$ & $0.048 \pm 0.001 \mathrm{~d}$ \\
A4 & $11.22 \pm 0.07 \mathrm{abc}$ & $2.91 \pm 0.01 \mathrm{a}$ & $2.09 \pm 0.01$ & $\mathrm{ND}$ & $0.050 \pm 0.001 \mathrm{~d}$ \\
\hline
\end{tabular}

Values with different small row (a-f) show significant differences among acid content in the same column. 
Table 2. Carbohydrate fermentation of L. plantarum strain.

\begin{tabular}{ccc}
\hline Carbohydrate & L. Plantarum M1 & L. Plantarum M3 \\
\hline Arabinose & + & + \\
Cellobiose & + & + \\
Fructose & + & + \\
Galactose & + & + \\
Glucose & + & + \\
Lactose & + & + \\
Maltose & + & + \\
Mannose & + & + \\
Raffinose & + & - \\
Rhamnose & - & + \\
Sucrose & + & + \\
Xylose & + &
\end{tabular}

The symbols represent the growth of the strains on the solid medium containing carbohydrate, + , normal; - , no growth.

\subsection{Chemical Composition of Fresh Alfalfa}

The chemical composition of fresh alfalfa was tested after it was wilted. The WSC, CP, NDF, and ADF content of the alfalfa were $5.65 \%, 20.58 \%, 39.42 \%$, and $29.29 \% \mathrm{DM}$, respectively. $\mathrm{Th}^{\mathrm{N}} \mathrm{NH}_{3}-\mathrm{N} / \mathrm{TN}$ was $3.09 \%$.

\subsection{The Fermentation Characteristics of Alfalfa Silage}

The fermentation characteristics and PLA content of alfalfa silage are shown in Table 3 . As indicated in Table 3, after 45 days of ensiling, the silages treated with PLA had lower $\mathrm{pH}$ values.

Table 3. Effect of lactobacillus bacteria and phenyllactic acid on the fermentation characters of alfalfa silages.

\begin{tabular}{|c|c|c|c|c|c|c|c|}
\hline Strains ${ }^{1}$ & $\begin{array}{l}\text { Initial } \\
\text { Content } \\
\text { of PLA }\end{array}$ & $\mathrm{pH}$ & $\begin{array}{l}\text { Lactic Acid } \\
\left(\% \mathrm{DM}^{2}\right)\end{array}$ & $\begin{array}{l}\text { Acetic Acid } \\
\text { (\% DM) }\end{array}$ & $\begin{array}{l}\text { Propionic } \\
\text { Acid } \\
\text { (\% DM) }\end{array}$ & $\begin{array}{l}\text { Butyric } \\
\text { Acid } \\
\text { (\% DM) }\end{array}$ & $\begin{array}{c}\text { Phenyllactic } \\
\text { Acid } \\
\text { (\%o DM) }\end{array}$ \\
\hline \multirow{4}{*}{ CK } & $0 \%$ & $4.65 \pm 0.07 a$ & $4.17 \pm 0.02 \mathrm{~d}$ & $2.75 \pm 0.19 \mathrm{~d}$ & $0.64 \pm 0.03 c$ & $\mathrm{ND}^{3}$ & $0.04 \pm 0.00 b$ \\
\hline & $0.1 \%$ & $4.54 \pm 0.04 b$ & $4.36 \pm 0.09 c d$ & $3.04 \pm 0.04 b c$ & $0.64 \pm 0.06 c$ & ND & $0.08 \pm 0.00 \mathrm{a}$ \\
\hline & $0.2 \%$ & $4.43 \pm 0.14 c$ & $5.16 \pm 0.38 \mathrm{ab}$ & $2.94 \pm 0.20 \mathrm{bcd}$ & $0.55 \pm 0.02 c$ & ND & $0.05 \pm 0.00 \mathrm{a}$ \\
\hline & $0.3 \%$ & $4.00 \pm 0.03 \mathrm{~g}$ & $5.85 \pm 016 a$ & $2.84 \pm 0.06 \mathrm{~cd}$ & $0.83 \pm 0.06 b$ & ND & $0.07 \pm 0.01 a$ \\
\hline \multirow{4}{*}{ M1 } & $0 \%$ & $4.13 \pm 0.03 e$ & $5.14 \pm 0.05 \mathrm{ab}$ & $3.33 \pm 0.06 a$ & $0.91 \pm 0.12 b$ & ND & $0.03 \pm 0.00 \mathrm{~b}$ \\
\hline & $0.1 \%$ & $4.06 \pm 0.01 \mathrm{efg}$ & $4.95 \pm 0.63 b c$ & $2.98 \pm 0.21 b c d$ & $0.89 \pm 0.07 b$ & ND & $0.04 \pm 0.01 a$ \\
\hline & $0.2 \%$ & $4.03 \pm 0.02 \mathrm{fg}$ & $4.96 \pm 0.18 b c$ & $2.77 \pm 0.08 \mathrm{~d}$ & $0.93 \pm 0.01 b$ & ND & $0.05 \pm 0.00 \mathrm{a}$ \\
\hline & $0.3 \%$ & $3.99 \pm 0.02 \mathrm{~g}$ & $5.86 \pm 0.05 a$ & $3.17 \pm 0.15 \mathrm{ab}$ & $1.12 \pm 0.06 a$ & ND & $0.05 \pm 0.00 \mathrm{a}$ \\
\hline \multirow{4}{*}{ M3 } & $0 \%$ & $4.29 \pm 0.01 d$ & $4.14 \pm 0.17 d$ & $3.16 \pm 0.09 a b$ & $1.08 \pm 0.10 \mathrm{a}$ & ND & $0.03 \pm 0.01 b$ \\
\hline & $0.1 \%$ & $4.10 \pm 0.02 \mathrm{ef}$ & $5.88 \pm 0.06 a$ & $3.06 \pm 0.03 b c$ & $1.05 \pm 0.00 \mathrm{a}$ & ND & $0.02 \pm 0.00 b$ \\
\hline & $0.2 \%$ & $3.99 \pm 0.04 \mathrm{~g}$ & $5.68 \pm 0.15 a b$ & $2.85 \pm 0.03$ & $1.10 \pm 0.02 \mathrm{a}$ & ND & $0.03 \pm 0.01 b$ \\
\hline & $0.3 \%$ & $4.06 \pm 0.02 \mathrm{efg}$ & $5.71 \pm 0.10 \mathrm{ab}$ & $3.12 \pm 0.10 \mathrm{ab}$ & $1.10 \pm 0.02 \mathrm{a}$ & ND & $0.04 \pm 0.00 b$ \\
\hline \multirow{3}{*}{ Significant } & Strains & * & $* *$ & $* *$ & $* *$ & & $* *$ \\
\hline & $\mathrm{C}_{\mathrm{PLA}}{ }^{4}$ & $* *$ & $* *$ & $* *$ & ** & & $* *$ \\
\hline & I & $* *$ & $* *$ & $* *$ & * & & $* *$ \\
\hline
\end{tabular}

Means with different small row (a-f) show significant differences $(p<0.05)$ among ensiling days in the same column. ** Significant at $p<0.01$; ${ }^{*}$ significant at $p<0.05$; NS, not significant at $p<0.05 ;{ }^{1}$ CK, no additive control; M1, Lactobacillus plantarum M1; M3, Lactobacillus plantarum M3; PLA, 3-phenyllactic acid; ${ }^{2}$ DM, dry matter; ${ }^{3} \mathrm{ND}$, not detected; ${ }^{4} \mathrm{C}_{\mathrm{PLA}}$, initial content of PLA; I, interaction between treatments and initial content of PLA. Values with different small row $(a-f)$ show significant differences among acid content in the same column.

The effect of PLA on the content of LA, AA, PA, and PLA in silage was significant $(p<0.01)$. BA was not detectable in the silage. The $\mathrm{pH}$ values decreased when PLA was used as an additive. The two selected strains or PLA significantly $(p<0.01)$ increased the content of lactic acid in silage compared with the control. The higher PLA concentrations in the control group than in the control group might be derived from the Phe generated by protein degradation. 
The content of $\mathrm{O}_{2}$ in the early ensiling period promotes the growth of fungi, and the fungi compete with the growth of LAB, resulting in DM loss or even failure in ensiling. During the process of alfalfa ensiling, the initial populations of fungi might have little effect on fermentation based on the observation that the LAB fermented rapidly. The inoculant PLA might inhibit the growth of fungi in early ensiling and have no effect on LAB fermentation. Thus, the silages treated with PLA showed significantly lower $(p<0.01) \mathrm{pH}$ values than the control after 45 days of ensiling.

\subsection{The Nutrient Characteristics of Alfalfa Silage}

The contents of nutrient substances are shown in Table 4 . These results indicated that the PLA and LAB strains had higher crude protein contents $(p<0.05)$. The NDF, ADF, and ammonia nitrogen contents in silage and ensiled for 45 days were obviously lower $(p<0.05)$ than those in CK.

Table 4. Effect of lactobacillus bacteria and phenyllactic acid on the nutrition characteristics and concentrations of structural carbohydrates in alfalfa silages.

\begin{tabular}{|c|c|c|c|c|c|c|c|}
\hline \multirow{2}{*}{ Strains ${ }^{1}$} & \multirow{2}{*}{$\begin{array}{c}\text { Initial } \\
\text { Content } \\
\text { of PLA }\end{array}$} & \multicolumn{6}{|c|}{ Items $^{2}$} \\
\hline & & $\begin{array}{c}\text { DM } \\
\left(\% \mathrm{FM}^{3}\right)\end{array}$ & $\begin{array}{c}\mathrm{CP} \\
(\% \mathrm{DM})\end{array}$ & $\begin{array}{c}\text { WSC } \\
\text { (\%DM) }\end{array}$ & $\begin{array}{c}\text { NDF } \\
(\% D M)\end{array}$ & $\begin{array}{c}\text { ADF } \\
(\% D M)\end{array}$ & $\begin{array}{l}\text { Ammonia } \\
\text { Nitrogen } \\
\left(\% \text { TN }^{4}\right)\end{array}$ \\
\hline \multirow{4}{*}{ CK } & $0 \%$ & $25.64 \pm 0.94 b$ & $20.04 \pm 0.27 d$ & $1.95 \pm 0.41 b$ & $44.65 \pm 0.34 a$ & $34.41 \pm 0.29 \mathrm{ab}$ & $11.28 \pm 0.75 a$ \\
\hline & $1.0 \%$ & $24.26 \pm 0.17 c$ & $20.37 \pm 0.18 b c d$ & $2.19 \pm 0.44 \mathrm{ab}$ & $44.62 \pm 0.48 a$ & $34.64 \pm 0.37 \mathrm{ab}$ & $11.01 \pm 0.39 a$ \\
\hline & $2.0 \%$ & $23.76 \pm 0.50 c$ & $20.58 \pm 0.38 b c d$ & $2.06 \pm 0.13 \mathrm{ab}$ & $44.20 \pm 0.51 a$ & $33.32 \pm 0.81 \mathrm{~cd}$ & $10.39 \pm 0.96 a b$ \\
\hline & $3.0 \%$ & $26.24 \pm 0.12 b$ & $20.49 \pm 0.14 \mathrm{bcd}$ & $2.11 \pm 0.09 b$ & $43.11 \pm 0.12 b$ & $33.92 \pm 0.45 b c$ & $7.58 \pm 0.10 \mathrm{e}$ \\
\hline \multirow{4}{*}{ M1 } & $0 \%$ о & $24.16 \pm 0.29 c$ & $20.38 \pm 0.17 b c d$ & $2.37 \pm 0.27 \mathrm{ab}$ & $42.57 \pm 0.19 b$ & $32.52 \pm 0.54 \mathrm{ef}$ & $8.94 \pm 0.67 c d$ \\
\hline & $1.0 \%$ & $26.46 \pm 0.44 b$ & $20.77 \pm 0.41 b c$ & $2.28 \pm 0.16 \mathrm{ab}$ & $42.36 \pm 0.48 b$ & $32.11 \pm 0.11 \mathrm{de}$ & $7.75 \pm 0.64$ de \\
\hline & $2.0 \%$ & $26.53 \pm 0.16 b$ & $20.88 \pm 0.26 b$ & $2.72 \pm 0.51 \mathrm{a}$ & $42.53 \pm 0.13 b$ & $31.96 \pm 0.24 \mathrm{fg}$ & $7.16 \pm 1.29 \mathrm{e}$ \\
\hline & $3.0 \%$ & $26.13 \pm 0.64 b$ & $21.62 \pm 0.32 a$ & $2.15 \pm 0.14 \mathrm{ab}$ & $41.05 \pm 0.31 c$ & $31.08 \pm 0.25 \mathrm{~h}$ & $6.82 \pm 0.64 \mathrm{e}$ \\
\hline \multirow{4}{*}{ M3 } & $0 \%$ & $28.38 \pm 0.36 a$ & $20.19 \pm 0.14 c d$ & $1.88 \pm 0.28 b$ & $42.61 \pm 0.49 b$ & $31.69 \pm 0.38 \mathrm{gh}$ & $9.33 \pm 0.37 \mathrm{ab}$ \\
\hline & $1.0 \%$ & $27.81 \pm 0.20 \mathrm{a}$ & $20.43 \pm 0.57 b c d$ & $2.21 \pm 0.22 \mathrm{ab}$ & $40.09 \pm 0.79 c$ & $31.00 \pm 0.28 \mathrm{~h}$ & $8.05 \pm 0.20 \mathrm{de}$ \\
\hline & $2.0 \%$ & $28.01 \pm 0.63 a$ & $20.53 \pm 0.26 b c d$ & $1.95 \pm 0.42 b$ & $41.51 \pm 0.37 c$ & $31.54 \pm 0.35 \mathrm{gh}$ & $7.47 \pm 0.47 \mathrm{e}$ \\
\hline & $3.0 \%$ & $27.51 \pm 0.72 a$ & $20.59 \pm 0.37 \mathrm{bcd}$ & $2.16 \pm 0.24 \mathrm{ab}$ & $40.97 \pm 007 \mathrm{c}$ & $32.10 \pm 0.25 \mathrm{fg}$ & $7.11 \pm 0.15 \mathrm{e}$ \\
\hline \multirow{3}{*}{ Significant } & Strains & NS & $* *$ & * & $* *$ & $* *$ & ** \\
\hline & $\mathrm{C}_{\mathrm{PLA}}{ }^{5}$ & NS & $* *$ & NS & $* *$ & $* *$ & $* *$ \\
\hline & $\mathrm{I}^{6}$ & NS & NS & NS & NS & $* *$ & * \\
\hline
\end{tabular}

Means with different small row (a-f) show significant differences $(p<0.05)$ among ensiling days in the same column.

** Significant at $p<0.01 ;{ }^{*}$ significant at $p<0.05$; NS, not significant at $p<0.05$. ${ }^{1} \mathrm{CK}$, no additive control; M1, Lactobacillus plantarum M1; M3, Lactobacillus plantarum M3; PLA, 3-phenyllactic acid; ${ }^{2}$ DM, dry matter; WSC, water soluble carbohydrates; NDF, neutral detergent fiber; ADF, acid detergent fiber; ADL, acid detergent lignin; ND, not detected; ${ }^{3} \mathrm{FM}$, fresh material; ${ }^{4} \mathrm{TN}$, total nitrogen; ${ }^{5} \mathrm{C}_{\mathrm{PLA}}$, initial content of PLA; ${ }^{6} \mathrm{I}$, interaction between treatments and initial content of PLA. Values with different small row (a-f) show significant differences among acid content in the same column.

\subsection{Correlation Analysis between Silage Fermentation and Treatments}

To investigate the relationship between chemical and fermentation characteristics, Spearman-related analysis was performed to determine the correlation of the variables. The results (Figure 3) showed that the PLA content was positively correlated with $\mathrm{pH}, \mathrm{NH}_{3}-\mathrm{N}, \mathrm{NDF}$, and ADF and negatively correlated with LA, AA, and PA contents during ensiling. The LA content was positively correlated with $\mathrm{AA}, \mathrm{PA}$, and $\mathrm{CP}$ and negatively correlated with the PLA, $\mathrm{DM}, \mathrm{pH}, \mathrm{NH}_{3}-\mathrm{N}, \mathrm{NDF}$, and $\mathrm{ADF}$ contents during ensiling. It was obvious that the LA, AA, and PA were mostly generated by LAB species in the sealed silos. These results suggested that PLA in the alfalfa silage was not solely generated by LAB species during ensiling. The content of PLA in the alfalfa silage treated by M1 was higher than that in the silage treated by M3, suggesting that the PLA content was positively related to the PLA productivity of LAB additives. However, other microorganisms might biotransfer PLA. 


\section{LA AA PA PLA DM pH NH3-N CP WSC NDF ADF}

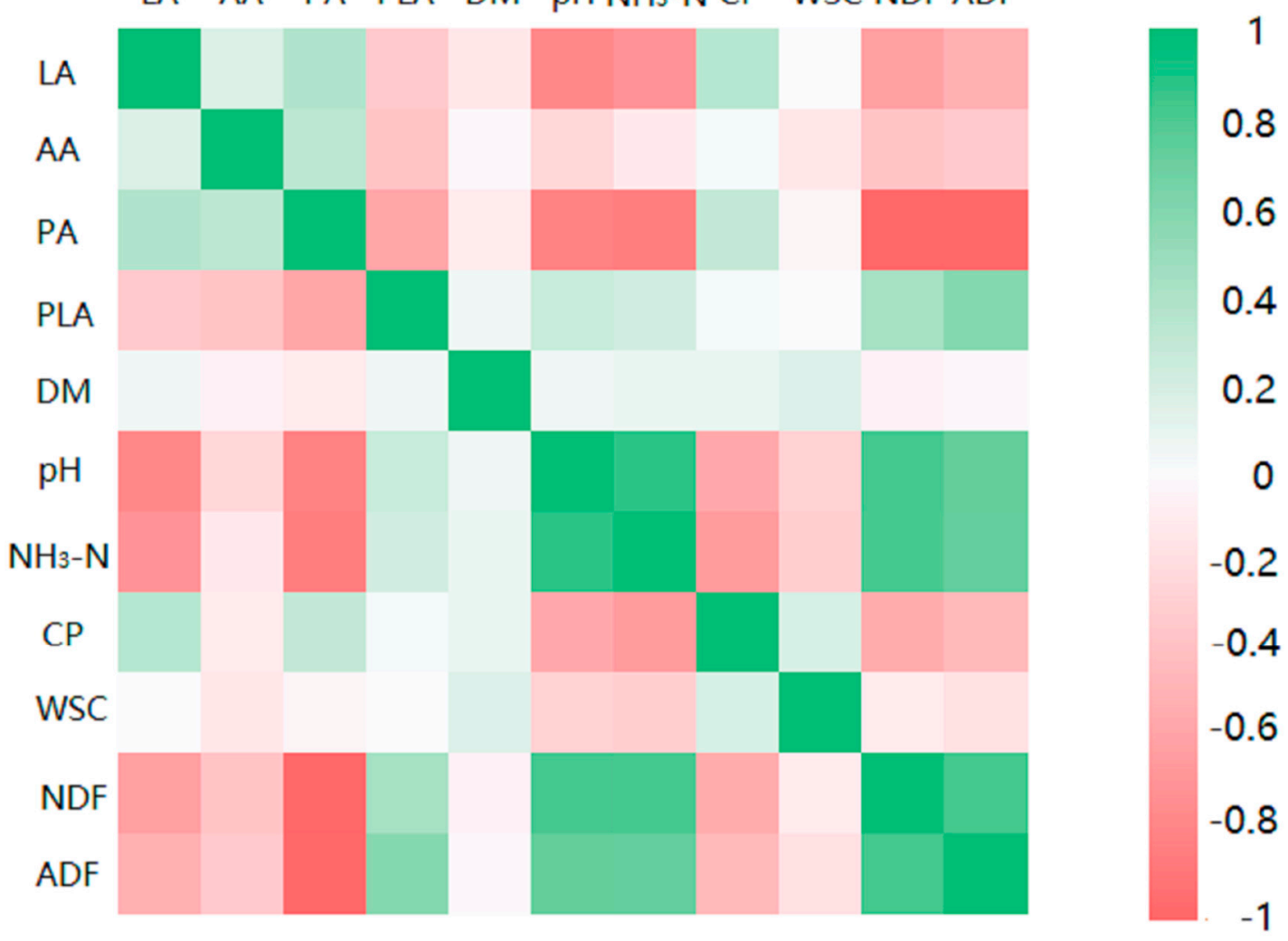

Figure 3. Spearman correlation between the fermentation indices in alfalfa silage after 45 days of ensiling. LA, lactic acid; AA, acetic acid; PA, propionic acid; PLA, phenyllactic acid; DM, dry matter; NH3-N, ammonia nitrogen; CP, crude protein; WSC, water soluble carbonhydrate; NDF, neutral detergent fibre; ADF, acid detergent fibre. The color means the significant correlation $(p<0.05)$; the deeper color of the square, the more significant the correlation.

\section{Discussion}

Homofermentative and heterofermentative LAB are often used as silage inoculants, to produce lactic acid and reduce $\mathrm{pH}$ rapidly, which create unfavorable conditions for the growth of mold, Clostridium, Acetobacter, and other microbes. For a long time, the growth rate and the ability to reduce the $\mathrm{pH}$ of the medium were two rules for selecting LAB as inoculants [21,22]. However, currently, biofunctional $\mathrm{LAB}$ are more favorable $[4,23]$. The metabolite analysis indicated that some inoculants produced more amino acids, organic acids, and phenolic acids in the silage samples than in the blank control-treated silage [23]. In the reports of Jin et al., FAE-producing L. buchneri increased the NDF digestibility of small-grain silage in situ [24]. Li et al. isolated two bacterial strains that demonstrated cellulolytic potential from Tibetan yak rumen and found that the strains increased the WSC contents of Pennisetum sinese silage [25].

The alfalfa proteins gradually degraded during ensiling. Others have used various strategies to reduce the proteolysis of alfalfa [1]. Tannins have been used because they reversibly bind proteins [1]. Formic acid can effectively prevent proteolysis by decreasing $\mathrm{pH}$ and inhibiting proteases [3]. Antimicrobial formaldehyde can form crosslinks between protein chains, thus reducing protein degradability [3]. LAB and previously fermented juice were used for the accumulation of lactic acid at early stages of ensiling [5].

A phenolic-related antibiotic (PLA) from L. plantarum was identified by Arasu [26]. In this work, several LAB strains were selected, and their PLA productivities were analyzed. L. plantarum M1 produced more PLA in MRS medium and alfalfa silage than L. plantarum M3. Then, the two strains 
and PLA showed the ability to improve the quality of alfalfa silage, especially in decreasing the content of $\mathrm{NH}_{3}-\mathrm{N}$. The $\mathrm{NH}_{3}-\mathrm{N}$ is an important index of protein degradation.

$\mathrm{Xu}$ et al. found PLA and other metabolites with bacteriostatic activity in whole-crop corn silage, but the treatments had no significant effect on the metabolites [20]. The PLA content was recorded in frozen, grass-dominated crop silages inoculated with LAB [27]. The concentration of PLA first increased and then decreased as the incubation time increased. However, until now, limited studies have been reported on PLA. Most of the reports analyzed gramineae silage [27], and the PLA was positively related to the abundance of L. acetotolerans in whole-crop corn silage [20]. In this work, the PLA content was related to the content of $\mathrm{NH}_{3}-\mathrm{N}$, indicating that the PLA produced during alfalfa ensiling was different from that produced during corn ensiling.

The phenethylamine was biotransformed from Phe by L-phenylalanine carboxy-lyase. The relative concentration of phenethylamine in the $\mathrm{NH}_{3}-\mathrm{N}$-rich silage was higher than that in other silage. The Phe may be formed in two ways, as indicated in Figure 1: one is the phenylalanine biosynthesis, and the other is by protein degradation. It was reported that Clostridium sporogenes could ferment L-phenylalanine to ammonia, $\mathrm{CO}_{2}, \mathrm{PLA}$ and 3-phenylpropionate [28]. Based on the relationship between the $\mathrm{NH}_{3}-\mathrm{N}$ and PLA contents at the end of silage, the activities of Clostridium during ensiling promoted the production of PLA from Phe generated during proteolysis. Moreover, the content of PLA in MRS medium was higher than that in alfalfa silages, which may be ascribed to the higher availability of amino acids (especially Phe) in the MRS medium compared with that in silages. A similar phenomenon occurred in PLA production by the same strain in MRS broth and in pickles [9]. Other studies have increased PLA production by adding Phe to mustard pickles and synthetic media [9,29]. The PLA was biotransformed from Phe in the raw materials. The difference in the PLA content could be attributed to different amino acid contents in MRS and in alfalfa silage. The Phe was biosynthesized to PLA with a relatively low conversion rate because the rate of transamination was limited; Phe was consumed by other reaction, and LAB provided an insufficient supply of electron acceptors.

Compared with ordinary preservatives, low PLA content improved the quality of alfalfa silage. In practice, ordinary organic acids may cause corrosion of machinery. In this study, the content of PLA was significantly lower than that of ordinary preservatives. In addition, the lactate content remarkably increased with increasing PLA content, indicating that the growth and metabolic activity of LAB strains were unaffected. The content of $\mathrm{CP}$ and $\mathrm{NH}_{3}-\mathrm{N}$ were significantly affected by the PLA and LAB strains. The lowest $\mathrm{NH}_{3}-\mathrm{N}$, lowest $\mathrm{ADF}$, and highest $\mathrm{CP}$ content were obtained in the alfalfa silage treated with $\mathrm{M} 1$ and $0.3 \%$ PLA, indicating that the biofunctional compound and its producing strains could be used as additives of alfalfa silage, to decrease protein degradation and increase the feed value.

On the other hand, PLA might function as a supplement in farm-animal feed. Phe cannot be synthesized by animals. The additional Phe by infusing increased the yield, and protein content of milk. D-Phe and L-PLA have similar efficacy when used to supplement a Phe-deficient diet or when fed as a source of dietary Phe [11]. PLA could be bioconverted to Phe by bacteria and fungi and used as a supplementary essential amino acid by animals. Thus, PLA might act as an amino acid supplement and antifungal compound when used in silage.

The selected strains exhibited high PLA productivity and low $\mathrm{NH}_{3}-\mathrm{N}$ content when used as additives in alfalfa silage, indicating that, in addition to lactic acid and acetic acid, the PLA generated by LAB strains was also important for the quality of alfalfa silage. Currently, the functional compounds generated by LAB strains are important for improving aerobic stability [22] and the silage quality, thus providing new ideas for screening for silage addictive.

\section{Conclusions}

The results indicate that PLA improves the quality of alfalfa silage. The chemical additive PLA effectively prevents crude protein in silage from degrading, even at low concentrations. LAB strains that produced high concentrations of PLA could also prevent protein degradation during the ensiling period. The results in this work provide a new way to explore silage addictive. 
Author Contributions: Conceptualization, methodology, funding acquisition, supervision, writing-original draft preparation, and writing-review and editing, Z.W.; investigation and data curation, S.X. and Y.Y.; data curation, T.J.; supervision and funding acquisition, Z.Y. All authors have read and agreed to the published version of the manuscript.

Funding: The authors thank the financial support from Modern Agro-Industry Technology Research System (CARS-35), the National Natural Science Foundation of China (31702181), the National Key Research and Development Program of China (2017YFD0502100), College and Discipline Autonomous Projects of China Agricultural University (31051601), and the Demonstration Project of Exploitation and Utilization of High Quality Green and Rough Feed Resources (16190051).

Conflicts of Interest: The authors declare no conflict of interest.

\section{References}

1. Tabacco, E.; Borreani, G.; Crovetto, G.M.; Galassi, G.; Colombo, D.; Cavallarin, L. Effect of chestnut tannin on fermentation quality, proteolysis, and protein rumen degradability of alfalfa silage. J. Dairy Sci. 2006, 89, 4736-4746. [CrossRef]

2. Owens, V.N.; Albrecht, K.A.; Muck, R.E. Protein degradation and fermentation characteristics of unwilted red clover and alfalfa silage harvested at various times during the day. Grass Forage Sci. 2002, 57, 329-341. [CrossRef]

3. Nagel, S.A.; Broderick, G.A. Effect of formic-acid or formaldehyde treatment of alfalfa silage on nutrient utilization by dairy-cows. J. Dairy Sci. 1992, 75, 140-154. [CrossRef]

4. Su, R.; Ni, K.; Wang, T.; Yang, X.; Zhang, J.; Liu, Y.; Shi, W.; Yan, L.; Jie, C.; Zhong, J. Effects of ferulic acid esterase-producing Lactobacillus fermentum and cellulase additives on the fermentation quality and microbial community of alfalfa silage. PeerJ 2019, 7, e7712. [CrossRef] [PubMed]

5. Wang, J.; Wang, J.Q.; Zhou, H.; Feng, T. Effects of addition of previously fermented juice prepared from alfalfa on fermentation quality and protein degradation of alfalfa silage. Anim. Feed Sci. Technol. 2009, 151, 280-290. [CrossRef]

6. Szumacher-Strabel, M.; Stochmal, A.; Cieslak, A.; Kozlowska, M.; Kuznicki, D.; Kowalczyk, M.; Oleszek, W. Structural and quantitative changes of saponins in fresh alfalfa compared to alfalfa silage. J. Sci. Food Agric. 2019, 99, 2243-2250. [CrossRef]

7. Jia, T.; Sun, Z.; Gao, R.; Yu, Z. Lactic acid bacterial inoculant effects on the vitamin content of alfalfa and Chinese leymus silage. Asian-Australas. J. Anim. Sci. 2019, 32, 1873-1881. [CrossRef]

8. Strom, K.; Sjogren, J.; Broberg, A.; Schnurer, J. Lactobacillus plantarum MiLAB 393 produces the antifungal cyclic dipeptides cyclo(L-Phe-L-Pro) and cyclo(L-Phe-trans-4-OH-L-Pro) and 3-phenyllactic acid. Appl. Environ. Microb. 2002, 68, 4322-4327. [CrossRef]

9. Li, X.; Ning, Y.; Liu, D.; Yan, A.; Wang, Z.; Wang, S.; Miao, M.; Zhu, H.; Jia, Y. Metabolic mechanism of phenyllactic acid naturally occurring in Chinese pickles. Food Chem. 2015, 186, 265-270. [CrossRef]

10. Dieuleveux, V.; Lemarinier, S.; Gueguen, M. Antimicrobial spectrum and target site of D-3-phenyllactic acid. Int. J. Food Microbiol. 1998, 40, 177-183. [CrossRef]

11. Prema, P.; Smila, D.; Palavesam, A.; Immanuel, G. Production and characterization of an antifungal compound (3-Phenyllactic Acid) produced by Lactobacillus plantarum strain. Food Bioprocess Technol. 2010, 3, 379-386. [CrossRef]

12. Mu, W.M.; Yu, S.H.; Zhu, L.J.; Zhang, T.; Jiang, B. Recent research on 3-phenyllactic acid, a broad-spectrum antimicrobial compound. Appl. Microbiol. Biot. 2012, 95, 1155-1163. [CrossRef] [PubMed]

13. Boebel, K.P.; Baker, D.H. Comparative utilization of the isomers of phenylalanine and phenyllactic acid by chicks and rats. J. Nutr. 1982, 112, 367-376. [CrossRef] [PubMed]

14. Wang, J.P.; Yoo, J.S.; Lee, J.H.; Zhou, T.X.; Jang, H.D.; Kim, H.J.; Kim, I.H. Effects of phenyllactic acid on production performance, egg quality parameters, and blood characteristics in laying hens. J. Appl. Poultry Res. 2009, 18, 203-209. [CrossRef]

15. Wang, J.P.; Yoo, J.S.; Lee, J.H.; Jang, H.D.; Kim, H.J.; Shin, S.O.; Seong, S.I.; Kim, I.H. Effects of phenyllactic acid on growth performance, nutrient digestibility, microbial shedding, and blood profile in pigs. J. Anim. Sci. 2009, 87, 3235-3243. [CrossRef] 
16. Assareh, R.; Zahiri, H.S.; Noghabi, K.A.; Aminzadeh, S.; Khaniki, G.B. Characterization of the newly isolated Geobacillus sp T1, the efficient cellulase-producer on untreated barley and wheat straws. Bioresour. Technol. 2012, 120, 99-105. [CrossRef]

17. Donnell, M.M.O.; Forde, B.M.; Neville, B.; Ross, P.R.; Toole, P.W.O. Carbohydrate catabolic flexibility in the mammalian intestinal commensal Lactobacillus ruminis revealed by fermentation studies aligned to genome annotations. Microb. Cell Fact. 2011, 10. [CrossRef]

18. Guo, J.G.; Xie, Y.X.; Yu, Z.; Meng, G.; Wu, Z. Effect of Lactobacillus plantarum expressing multifunctional glycoside hydrolases on the characteristics of alfalfa silage. Appl. Microbiol. Biot. 2019, 103, 7983-7995. [CrossRef]

19. Lavermicocca, P.; Valerio, F.; Visconti, A. Antifungal activity of phenyllactic acid against molds isolated from bakery products. Appl. Environ. Microb. 2003, 69, 634-640. [CrossRef]

20. Xu, D.M.; Ding, W.R.; Ke, W.C.; Li, F.H.; Zhang, P.; Guo, X.S. Modulation of metabolome and bacterial community in whole crop corn silage by inoculating homofermentative lactobacillus plantarum and heterofermentative Lactobacillus buchneri. Front. Microbiol. 2019, 9. [CrossRef]

21. Cai, Y.; Yang, J.; Pang, H.; Kitahara, M. Lactococcus fujiensis sp. nov., a lactic acid bacterium isolated from vegetable matter. Int. J. Syst. Evol. Microbiol. 2011, 61, 1590-1594. [CrossRef]

22. Liu, Q.H.; Yang, F.Y.; Zhang, J.G.; Shao, T. Characteristics of Lactobacillus parafarraginis ZH1 and its role in improving the aerobic stability of silages. J. Appl. Microbiol. 2014, 117, 405-416. [CrossRef]

23. Liu, Q.; Lindow, S.E.; Zhang, J. Lactobacillus parafarraginis ZH1 producing anti-yeast substances to improve the aerobic stability of silage. Anim. Sci. J. 2018, 89, 1302-1309. [CrossRef]

24. Jin, L.; Duniere, L.; Lynch, J.P.; Zaheer, R.; Turkington, K.; Blackshaw, R.E.; Lupwayi, N.Z.; O’Donovan, J.T.; Harker, K.N.; McAllister, T.; et al. Impact of ferulic acid esterase-producing lactobacilli and fibrolytic enzymes on ensiling and digestion kinetics of mixed small-grain silage. Grass Forage Sci. 2017, 72, 80-92. [CrossRef]

25. Li, J.; Yuan, X.; Desta, S.T.; Dong, Z.; Mugabe, W.; Shao, T. Characterization of Enterococcus faecalis JF85 and Enterococcus faecium Y83 isolated from Tibetan yak (Bos grunniens) for ensiling Pennisetum sinese. Bioresour. Technol. 2018, 257, 76-83. [CrossRef]

26. Valan Arasu, M.; Jung, M.W.; Ilavenil, S.; Jane, M.; Kim, D.H.; Lee, K.D.; Park, H.S.; Hur, T.Y.; Choi, G.J.; Lim, Y.C.; et al. Isolation and characterization of antifungal compound from Lactobacillus plantarum KCC-10 from forage silage with potential beneficial properties. J. Appl. Microbiol. 2013, 115, 1172-1185. [CrossRef]

27. Broberg, A.; Jacobsson, K.; Strom, K.; Schnurer, J. Metabolite profiles of lactic acid bacteria in grass silage. Appl. Environ. Microb. 2007, 73, 5547-5552. [CrossRef]

28. Dickert, S.; Pierik, A.J.; Buckel, W. Molecular characterization of phenyllactate dehydratase and its initiator from Clostridium sporogenes. Mol. Microbiol. 2002, 44, 49-60. [CrossRef]

29. Valerio, F.; Lavermicocca, P.; Pascale, M.; Visconti, A. Production of phenyllactic acid by lactic acid bacteria: An approach to the selection of strains contributing to food quality and preservation. FEMS Microbiol. Lett. 2004, 233, 289-295. [CrossRef]

(C) 2019 by the authors. Licensee MDPI, Basel, Switzerland. This article is an open access article distributed under the terms and conditions of the Creative Commons Attribution (CC BY) license (http://creativecommons.org/licenses/by/4.0/). 